\title{
PENGARUH KURS VALUTA ASING DAN TINGKAT BAGI HASIL TERHADAP VOLUME DEPOSITO MUDHARABAH USD PADA PERBANKAN SYARIAH (PERIODE JANUARI 2011- MARET 2015)
}

\author{
Rianti Pratiwi ${ }^{1}$ dan Asshiddiqi Lukmana ${ }^{2}$
}

1Program Studi Perbankan Syariah, Sekolah Tinggi Ekonomi Islam SEBI, Depok, Jawa Barat. Email: rianti.affandi@gmail.com

2Analisis Pembiayaan Syariah, Otomas Multifinance Syariah, Jakarta. Email: ass.diel@gmail.com

\begin{abstract}
ABSTRAK: Tujuan penelitian ini adalah untuk menganalisis pengaruh kurs USD dan tingkat bagi hasil deposito mudharabah USD terhadap volume deposito mudharabah USD pada perbankan syariah. Data yang digunakan pada penelitian ini adalah data bulanan dari Januari 2011 sampai Maret 2015. Penelitian ini menggunakan metode analisis linier regresi berganda dengan menggunakan program komputer SPSS versi 22.0 dan Microsoft Excel 2010. Hasil analisis menunjukkan bahwa secara parsial, kurs USD berpengaruh positf signifikan terhadap volume deposito mudharabah USD, sedangkan tingkat bagi hasil deposito mudharabah USD berpengaruh negatif tidak signifikan. Secara simultan variabel kurs USD dan tingkat bagi hasil deposito mudharabah USD berpengaruh signifikan terhadap volume deposito mudharabah USD. Hal ini dibuktikan dengan nilai sig-F 0,000 yang lebih kecil dari signifikansi 5\%. Kemampuan prediksi dari kedua variabel tersebut terhadap volume deposito mudharabah USD adalah 88,4\%. sebagaimana ditunjukkan oleh besarnya adjusted $R$ square, sedangkan sisanya 11,6\% dipengaruhi oleh faktor lain.
\end{abstract}

Kata Kunci : Kurs, Tingkat Bagi Hasil Deposito Mudharabah, Volume Deposito Mudharabah dan Analisis Regresi linier

ABSTRACT: The purpose of this study was to analyze the influence of the USD exchange rate and the rate for the mudharabah deposit for USD toward the volume of deposit of mudharabah. The data used in this study is the monthly data from January 2011 to March 2015. This study uses linear regression analysis using SPSS version 22.0 and Microsoft Excel 2010. The analysis showed that partially, the USD exchange rate impact positf significantly to the volume of deposits mudaraba USD, while the rate for the deposits of USD mudharabah significant negative effect. Simultaneously, USD rate and deposits of USD mudharabah significantly affect the volume of deposits mudarabah USD. This is evidenced by the value of sig-F 0,000 less than the 5\% significance. The predictive ability of the variables on the volume of deposits was $88.4 \%$ mudharabah USD. As indicated by the adjusted R-square, while the remaining $11.6 \%$ is influenced by other factors.

Keywords: kurs, Rate of Profit of Mudharabah Deposit, volume of Deposit, and regresseion analisys. 
56 | Pratiwi \& Lukmana: Pengaruh Kurs Valuta Asing dan Tingkat Bagi Hasil Terhadap Volume Deposito Mudharabah...

\section{PENDAHULUAN}

Bank Syariah adalah suatu lembaga keuangan yang usaha pokoknya memberikan pembiayaan dan jasa-jasa lainnya dalam lalu lintas pembayaran serta peredaran uang yang pengoperasiannya disesuaikan dengan prinsip-prinsip Islam (UU No. 10/1998). Bank Syariah didirikan dengan tujuan untuk mempromosikan dan mengembangkan penerapan prinsip-prinsip Islam sesuai Al-Qur'an dan Al-Hadist, khususnya dalam transaksi keuangan dan perbankan serta bisnis lain yang terkait. Prinsip-prinsip utama yang diikuti oleh bank syariah adalah larangan riba (suku bunga) dalam berbagai bentuk transaksi, melakukan kegiatan usaha dan perdagangan berdasarkan perolehan keuntungan yang sah dan sesuai kesepakatan bersama (Sudarsono, 2003).

Peranan perbankan syariah dalam aktivitas ekonomi Indonesia tidak jauh berbeda dengan perbankan konvensional. Perbedaan mendasar antara keduanya adalah prinsipprinsip dalam transaksi keuangan/operasional. Salah satu prinsip dalam operasional perbankan syariah adalah penerapan bagi hasil dan risiko (profit and loss sharing). Prinsip ini tidak berlaku di perbankan konvensional yang menerapkan sistem bunga(Husni, 2009).

Salah satu faktor yang dapat mempengaruhi pertumbuhan bank adalah kemampuannya dalam menghimpun dana dari masyarakat, baik berskala kecil maupun besar. Tanpa dana yang cukup, bank tidak dapat berbuat apa-apa, bahkan tidak berfungsi sama sekali dan bahkan menjadi acuan apakah bank tersebut termasuk bank yang menguntungkan atau tidak, karena itulah dana merupakan elemen yang paling utama. Menempatkan uang di bank syariah termasuk kategori investasi. Besar kecilnya perolehan return tergantung pada hasil usaha yang benar-benar terjadi dan dilakukan oleh bank sebagai pengelola dana. (Wiroso, 2005).

Produk penghimpunan dana pihak ketiga pada bank syariah antara lain adalah deposito mudharabah. Pada bank syariah yang sudah menjadi bank devisa, bank juga dapat menghimpun dana melalui produk deposito mudharabah USD. Tidak berbeda dengan produk deposito mudharabah IDR, deposito mudharabah USD juga menerapkan prinsip investasi, dimana tentunya keuntungan yang didapat oleh deposan adalah bagi hasil dalam USD. Pada produk ini, risiko kurs atau perbedaan nilai mata uang rupiah dengan valuta asing sudah mulai diperhitungkan.

Penempatan dana valuta asing di bank sebenarnya merupakan salah satu alternatif sumber cadangan devisa negara. Termasuk di dalamnya deposito mudharabah USD pada perbankan syariah. Masyarakat domestik dapat diarahkan untuk menempatkan dananya ke deposito valuta asing sebagai salah satu upaya mencapai kemadirian sumber keuangan negara. Jika hal ini dapat dikelola secara baik oleh perbankan dan pemerintah maka setidaknya mengurangi ketergantungan negara terhadap bantuan dan pinjaman luar negeri. Dengan demikian pengetahuan tentang perilaku deposito valuta asing sangat penting dalam merancang kebijakan untuk mendorong sumber-sumber keuangan negara. (Kurniawan, 2003).

Dengan karakteristik perbankan syariah yang memiliki hubungan sangat erat dengan sektor riil, secara konseptual perkembangan perbankan syariah akan sangat dipengaruhi oleh perkembangan kondisi perekonomian nasional. Perubahan yang terjadi pada faktor-faktor makro dapat mempengaruhi penghimpunan deposito mudharabah baik secara positif atau negatif. Ini menandakan pengumpulan dana pihak ketiga pada 
Jurnal Ekonomi dan Perbankan Syariah

Vol. 3. No.1, April 2015: 55-60, ISSN (cet): 2355-1755

bank syariah tidak terlepas dari berbagai macam faktor yang mendasarinya tersebut. Faktor-faktor makro yang dapat mempengaruhi antara lain inflasi, kurs, tingkat suku bunga/bagi hasil deposito, dan volume bagi hasil deposito.

Salah satu faktor makro yang dapat mempengaruhi dana pihak ketiga (DPK) perbankan syariah adalah Kurs USD. Pada prinsipnya depresiasi IDR terhadap valas utamanya USD, dapat menyebabkan capital outflow atau pelarian modal masyarakat keluar negeri karena ekspektasi return investasi dalam IDR dianggap lebih rendah. Sedangkan dari sudut pandang nasabah pembiayaan, depresiasi IDR terhadap mata uang hard currencies seperti USD akan meningkatkan biaya produksi akibat kenaikan harga bahan mentah dan barang modal yang berasal dari impor. Akibatnya, perusahaan akan cenderung menarik dana likuid dengan return rendah untuk mengatasi masalah permodalannya. Semakin meningkat nilai tukar USD akan menaikkan permintaan Dollar, sebaliknya permintaan uang domestik akan turun. (Muttaqiena; 2013). Sehingga dapat dikatakan volume DPK USD perbankan syariah, termasuk didalamnya volume deposito mudharabah USD diharapkan akan mengalami peningkatan, berbanding lurus terhadap permintaan USD.

Namun demikian, dari data BI hingga awal semester tahun 2015, volume deposito Mudharabah USD mengalami penurunan, dari USD 654,6 juta pada Desember 2014 menjadi sebesar USD 611,8 juta pada Maret 2015. Hal ini terjadi di saat Rupiah sedang mengalami depresiasi terhadap nilai mata uang Dollar AS.

\section{Grafik 1.1 Perkembangan Volume Deposito Mudharabah (dalam jutaan USD)}

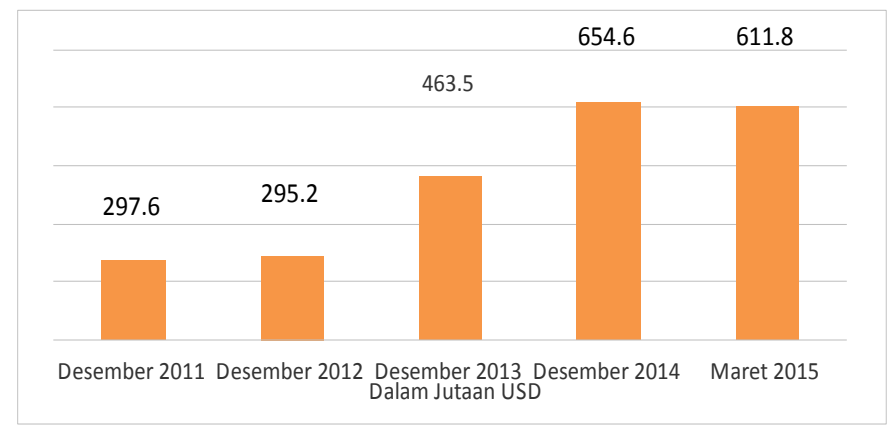

Sumber : Data Statistik Bank Indonesia, data diolah

\section{Grafik 1.2 Grafik Pergerakan Rupiah dari Tahun ke Tahun}

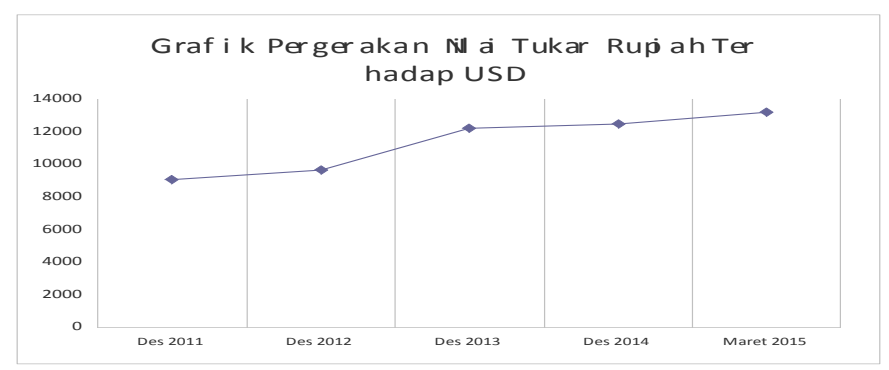

Sumber : Data Statistik Bank Indonesia, data diolah 
58 | Pratiwi \& Lukmana: Pengaruh Kurs Valuta Asing dan Tingkat Bagi Hasil Terhadap Volume Deposito Mudharabah...

Pelemahan Rupiah terjadi karena beberapa faktor eksternal selain faktor internal, seperti defisit neraca transaksi berjalan. Banyak pengaruhnya dari faktor eksternal, contohnya rencana AS untuk mengurangi stimulus moneter, dan penurunan hasil ekspor Indonesia. Ketika rupiah melemah, seharusnya ekspor mengalami kenaikan. Namun karena produk ekspor Indonesia didominasi barang komoditas yang harga dan permintaannya sedang anjlok, maka kontribusi terhadap neraca perdagangan tidak signifikan, sehingga Indonesia masih tetap mengalami defisit, dan pertumbuhan ekonomi juga menurun. Kondisi tersebut mendorong pelemahan Rupiah.

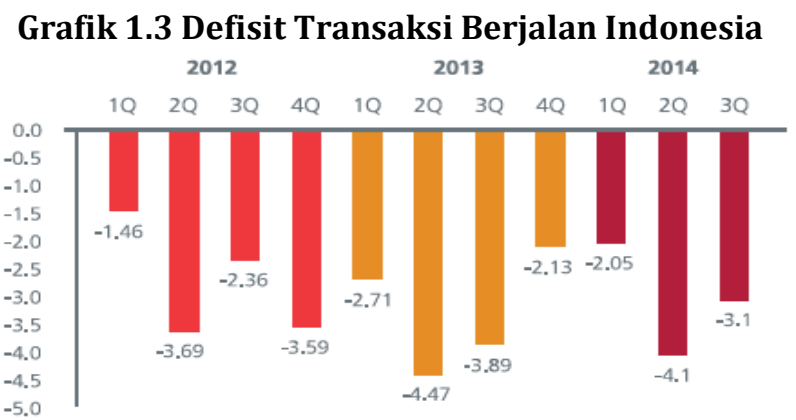

Sumber: Eastspring investments. 2015. "Market Outlook 2015".

Grafik 1.4 Pertumbuhan Ekonomi Indonesia

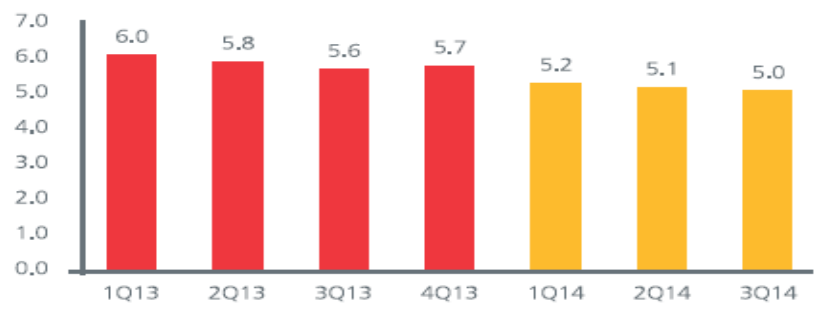

Sumber: Eastspring investments. 2015. "Market Outlook 2015".

Selain itu merosotnya pergerakan rupiah juga didukung kecenderungan melambatnya ekonomi negara-negara berkembang, seperti China dan India. Sedangkan dengan negara-negara maju terjadi pemulihan ekonomi.

Grafik 1.5 Pertumbuhan Negara Lain

\begin{tabular}{|l|c|c|c|c|c|c|c|}
\hline & $\mathbf{1 Q 1 3}$ & $\mathbf{2 Q 1 3}$ & $\mathbf{3 Q 1 3}$ & $\mathbf{4 Q 1 3}$ & $\mathbf{1 Q 1 4}$ & $\mathbf{2 Q 1 4}$ & $\mathbf{3 Q 1 4}$ \\
\hline Amerika Serikat & 2,7 & 1,8 & 4,5 & 3,5 & $(2,1)$ & 4,6 & 5,0 \\
\hline Eropa & $(1,1)$ & $(0,6)$ & $(0,3)$ & 0,4 & 1,0 & 0,8 & 0,8 \\
\hline China & 7,7 & 7,5 & 7,8 & 7,7 & 7,4 & 7,5 & 7,3 \\
\hline
\end{tabular}

Sumber: Eastspring investments. 2015. "Market Outlook 2015”.

Konsep perbankan syariah menjaga keseimbangan antara sektor riil dengan sektor moneter, sehingga pertumbuhan pembiayaannya tidak akan lepas dari pertumbuhan sektor riil yang dibiayainya. Pada saat perekonomian dunia lesu, maka yield yang 
Jurnal Ekonomi dan Perbankan Syariah

Vol. 3. No.1, April 2015: 55-60, ISSN (cet): 2355-1755

diterima oleh perbankan syariah juga menurun, dan pada gilirannya return yang dibagi hasilkan kepada para penabung/deposan juga turun. Sebaliknya, pada saat perekonomian booming, maka return yang dibagi hasilkan akan naik pula. Dengan kata lain, kinerja perbankan syariah ditentukan oleh kinerja sektor ril, dan bukan sebaliknya. Dengan demikian, sejalan dengan lesu nya perekonomian, dikhawatirkan yield/ bagi hasil deposan juga akan semakin rendah. Hal ini akan menyebabkan daya tarik penghimpunan dana di bank syariah akan berkurang, dan ujungnya dapat berdampak negatif kepada penyaluran dana ke sektor riil. Berikut tingkat bagi hasil deposito Mudharabah USD.

\section{Grafik 1.6 Perkembangan Deposito Mudharabah USD}

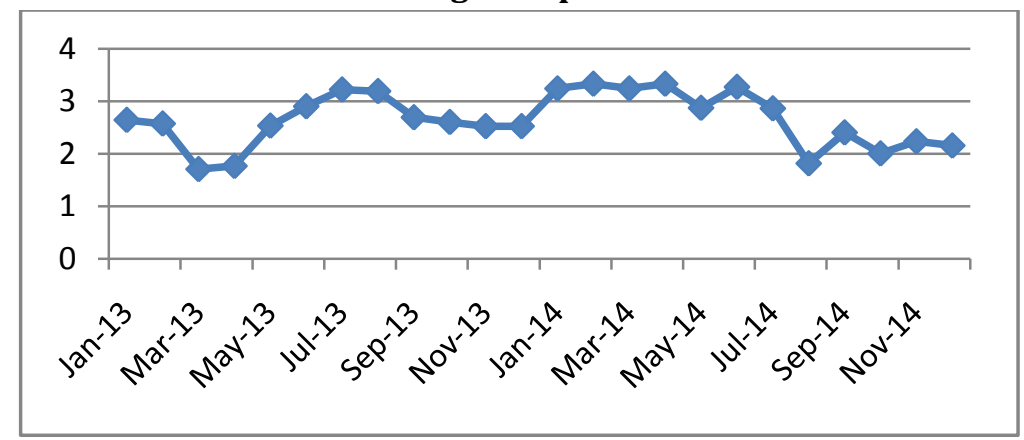

Sumber : Data statistik Bank Indonesia, data diolah

Terlihat bahwa nilai bagi hasil deposito mudharabah USD memiliki volatilitas yang tinggi dan bahkan cenderung menurun dipertengahan tahun 2014 hingga akhir tahun 2014.

\section{TELAAH PUSTAKA}

Bank Syariah menurut para ahli adalah lembaga keuangan yang usaha pokoknya memberikan kredit dan jasa-jasa lain dalam lalu lintas pembayaran serta peredaran uang yang beroperasi dengan prinsip-prinsip syariah. (Sudarsono, 2003). Penghimpunan dana di Bank Syariah dapat berbentuk giro, tabungan, dan deposito. Prinsip operasional syariah yang diterapkan dalam penghimpunan dana masyarakat adalah prinsip Wadi'ah dan Mudharabah. (Karim, 2004).

Menurut UU No. 21 tahun 2008 pasal 1 tentang perbankan syariah, deposito adalah investasi dana berdasarkan akad mudharabah atau akad lain yang tidak bertentangan dengan prinsip syariah yang penarikannya hanya dapat dilakukan pada waktu tertentu berdasarkan akad antara nasabah penyimpan dan Bank Syariah dan/atau UUS. Deposito mudharabah atau deposito syariah adalah deposito yang dijalankan berdasarkan prinsip syariah (Karim, 2004).

Deposito valas ini sangat strategis dalam membantu kegiatan operasional bank khususnya ruang lingkup bank itu sendiri. Jenis simpanan ini merupakan salah satu sumber utama modal bank yang praktis penggunaannya karena mempunyai limit waktu. Deposito valas ini bagi suatu bank berfungsi untuk memenuhi kebutuhan modal suatu bank, dan disamping itu juga membantu menjaga posisi likuiditas bank. Kebutuhan akan modal kerja suatu bank harus selalu dipenuhi setiap saat sehubungan dengan salah satu 
60 | Pratiwi \& Lukmana: Pengaruh Kurs Valuta Asing dan Tingkat Bagi Hasil Terhadap Volume Deposito Mudharabah...

fungsi utama bank yakni sebagai lembaga yang menyalurkan dana dari masyarakat dalam bentuk kredit atau sebagai lembaga pemberi kredit.

Disamping fungsi internal di dalam perbankan, terdapat pula fungsi ekstren, yakni dikaitkan dengan fungsi yang ada diluar perusahaan bank sebagai lembaga yang bergerak dalam bidang jasa yang memperlancar arus pembayaran uang. Dalam upaya mencapai dalam bidang tujuan pembangunan nasional diharapkan lembaga perbankan dapat berperan dalam mendukung peningkatan pertumbuhan ekonomi dan stabilitas nasional kearah peningkatan perkembangan perekonomian nasional maupun internasional yang senantiasa bergerak cepat disertai tantangan yang semakin luas, untuk itu bank harus mampu menghadapi persaingan yang sehat dan efisien. Deposito valas ini merupakan sarana penghimpunan dana dalam volume yang besar, dengan demikian pemerintah sangat mengharapkan inisiatif dari masyarakat untuk menanamkan dana yang lebih melalui deposito valas demi menunjang pembangunan yang senantiasa membutuhkan dana yang relative besar.

Kurs mata uang dapat diibaratkan sebagai harga dari mata uang itu. Sama seperti harga produk, harga suatu mata uang juga ditentukan oleh permintaan dan penawaran. Kurs terbentuk pada saat volume dan harga mata uang yang diminta sama dengan volume dan harga mata uang yang ditawarkan. Kondisi ini tersebut sebagai kondisi keseimbangan atau ekuilibrium. Kondisi keseimbangan dapat berubah setiap saat, jika faktor-faktor yang mempengaruhi permintaan dan/atau penawaran berubah. Permintaan terhadap suatu mata uang terbalik dengan harganya. Semakin tinggi nilai USD (misalnya terhadap Rupiah), maka keinginan untuk menukarkan Rupiah dengan USD akan semakin berkurang, dan begitu pula sebaliknya (Yuliati dan Prasetyo, 1998).

Sistem bagi hasil merupakan sistem di mana dilakukannya perjanjian atau ikatan bersama di dalam melakukan kegiatan usaha. Di dalam usaha tersebut diperjanjikan adanya pembagian hasil atas keuntungan yang akan di dapat antara kedua belah pihak atau lebih. Besarnya penentuan porsi bagi hasil antara kedua belah pihak ditentukan sesuai kesepakatan bersama, dan harus terjadi dengan adanya kerelaan (An-Tarodhin) di masing-masing pihak tanpa adanya unsur paksaan. Sehingga nilai bagi hasil deposito akan dipengaruhi oleh keuntungan yang didapatkan mudharib dari hasil pengelolaannya, sesuai dengan nisbah yang disepakati bersama shahibul mal. Dalam pandangan Islam, uang hanyalah sebagai alat tukar dan bukan merupakan barang dan komoditas. Islam tidak mengenal time value of money, tetapi islam mengenal economic value of time. Jadi dengan kata lain, yang berharga menurut pandangan Islam adalah waktu itu sendiri (Zainul, 2009).

\section{METODE PENELITIAN}

Jenis penelitian ini merupakan penelitian kuantitatif dengan desain uji hipotesis atas data sekunder berbentuk time series yang diperoleh dari data publikasi Bank Indonesia dari periode januari 2011- MAret 2015. Operasionalisasi variabel dalam penelitian ini terdiri atas :

1. Volume deposito Mudharabah USD (Y) : Pada penelitian ini, variabel terikatnya adalah volume deposito Mudharabah USD. Deposito Mudharabah USD adalah total dana nasabah yang disimpan dengan prinsip Mudharabah degan mata uang USD pada perbankan syariah di Bank Indonesia. Data operasional yang digunakan dalam 
Jurnal Ekonomi dan Perbankan Syariah

Vol. 3. No.1, April 2015: 55-60, ISSN (cet): 2355-1755

penelitian ini diperoleh dari Bank Indonesia, yaitu data Statistik Perbankan Syariah yang dinyatakan dalam satuan USD.

2. Kurs USD $\left(\mathrm{X}_{1}\right)$ : Kurs yang digunakan dalam penelitian ini adalah data kurs tengah nilai tukar rupiah terhadap dollar AS yang bersumber dari situs resmi Bank Indonesia yang dinyatakan dalam rupiah.

3. Bagi Hasil $\left(\mathrm{X}_{2}\right)$ : Bagi Hasil disini adalah presentase perolehan bagi hasil untuk nasabah pemilik deposito mudharabah USD yang menitipkan dananya pada bank tersebut. Data operasional yang digunakan dalam penelitian ini diperoleh dari data Statistik Perbankan Syariah yang dinyatakan dalam bentuk persen (\%).

Metode tersebut akan digunakan untuk menguji hipotesis berikut:

HO : Kurs USD dan tingkat bagi hasil tabungan Mudharabah USD tidak berpengaruh signifikan terhadap volume deposito Mudharabah USD Januari 2011 - Maret 2015 (secara parsial maupun simultan)

H1 : Kurs USD berpengaruh signifikan terhadap volume deposito Mudharabah USD Januari 2011 - Maret 2015.

H2 : Tingkat bagi hasil deposito mudharabah USD berpengaruh signifikan terhadap volume deposito Mudharabah USD Januari 2011 - Maret 2015.

H3 : Kurs USD dan tingkat bagi hasil deposito mudharabah USD berpengaruh signifikan terhadap volume deposito Mudharabah USD Januari 2011 - Maret 2015.

Untuk memastikan bahwa model yang diperoleh merupakan model yang tepat, maka sebelumnya akan dilakukan uji asumsi klasik yang terdiri atas Uji Multikolineritas, Uji Heterokedastisitas, dan Uji Autokorelasi. Model regresi yang diperoleh dari hasil penelitian dapat ditulis dalam bentuk persamaan:

$$
\mathrm{Y}=\mathrm{a}+\mathrm{b}_{1} \mathrm{X}_{1}+\mathrm{b}_{2} \mathrm{X}_{2}
$$

Keterangan:

Y : Volume deposito Mudharabah USD (variabel dependent)

$\mathrm{X} 1$ : Kurs USD (variabel independent)

X2 : Tingkat bagi hasil deposito Mudharabah USD (variabel independent)

a : Nilai konstanta

b : Nilai koefisien regresi

\section{HASIL DAN ANALISIS}

Berikut adalah hasil statistik deskriptif penelitian yang dapat dilihat pada tabel 4.1. Hasil Statistik Deskriptif:

Tabel 4.1. Hasil Statistik Deskriptif Descriptive Statistics

\begin{tabular}{|l|r|r|r|r|r|}
\hline & \multicolumn{1}{|c|}{ N } & \multicolumn{1}{|c|}{ Minimum } & \multicolumn{1}{c|}{ Maximum } & \multicolumn{1}{c|}{ Mean } & Std. Deviation \\
\hline $\mathrm{Y}$ & 51 & 156912544 & 686227446 & 385639839.43 & 171556553.930 \\
$\mathrm{X} 1$ & 51 & 8508.0 & 13084.0 & 10308.373 & 1422.7570 \\
$\mathrm{X} 2$ & 51 & 1.70 & 4.70 & 3.0018 & .71875 \\
Valid N & 51 & & & & \\
(listwise) & & & & & \\
\hline
\end{tabular}

Sumber: pengolahan data melalui SPSS 
62 | Pratiwi \& Lukmana: Pengaruh Kurs Valuta Asing dan Tingkat Bagi Hasil Terhadap Volume Deposito Mudharabah...

Dari tabel 4.1 di atas, dapat dilihat nilai $\mathrm{N}=51$ merupakan banyaknya data sampel (data bulanan selama 4 Tahun 3 Bulan). Data deposito yang digunakan dalam penelitian ini adalah volume deposito Mudharabah USD yang dihimpun Perbankan Syariah pada periode Januari 2011- Maret 2015 yang tercatat dalam statistik Bank Umum Syariah yang dipublikasi dalam situs www.bi.go.id. Kemudian dari tabel tersebut menunjukkan bahwa variabel terikat (dependent) volume deposito Mudharabah USD memiliki nilai minimum 156.912.544 pada bulan Januari 2015 sedangkan untuk nilai maksimumnya sebesar 686.227.446 pada bulan Oktober 2014. Nilai rata-rata Volume Deposito Mudharabah USD sebesar 385.639.839,43 dan standar deviasinya sebesar 171.556.553,930.

Variabel bebas Kurs USD memiliki nilai minimum 8.508 pada bulan Juli 2011 sedangkan untuk nilai maksimumnya sebesar 13.084 pada bulan Maret 2015. Nilai ratarata (mean) kurs USD 10.308 dan ukuran penyebaran data dari rata-ratanya (standar deviasi) sebesar 14.227.

Variabel bebas tingkat bagi hasil deposito mudharabah USD memiliki nilai minimum $1.70 \%$ pada bulan Maret 2013 sedangkan untuk nilai maksimumnya sebesar 4.70\% pada bulan Maret 2015. Nilai rata-rata (mean) 3.00\% dan ukuran penyebaran data dari rata-ratanya (standar deviasi) sebesar 7.18\%.

\section{Uji Asumsi Klasik}

\section{1) Uji Normalitas}

Uji normalitas dilakukan untuk melihat apakah variabel bebas dan variabel terikat mempunyai distribusi normal. Dalam penelitian ini, diggunakan uji normalitas dengan analisis grafik dan uji Kolmogorov-Smirnov. Berikut adalah hasil dari uji ini:

\section{Gambar 4.1 Histogram dan Normal Plot}
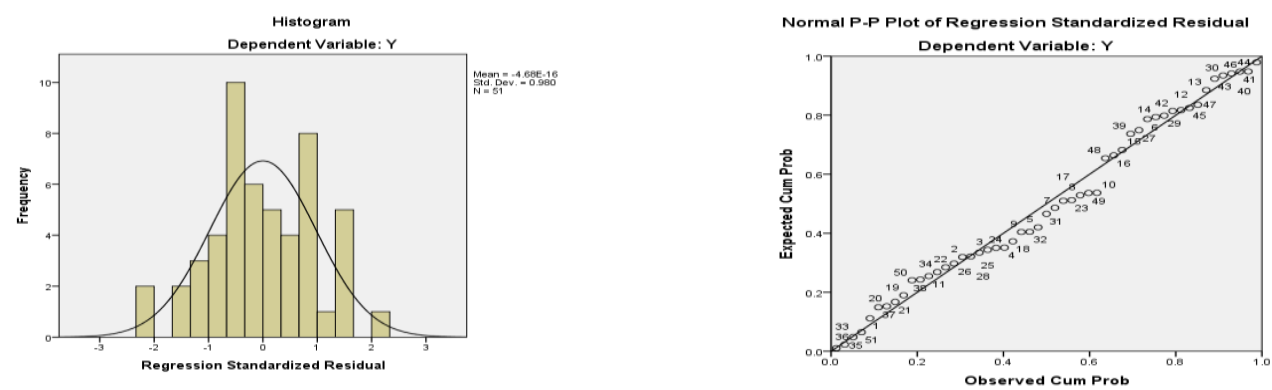

Sumber : SPSS Data diolah

Berdasarkan gambar diatas histogram Regression Residual membentuk kurva seperti lonceng maka nilai residual tersebut dinyatakan normal atau data berdistribusi normal. Sedangkan hasl normal plot diatas, titik-titik mengikuti atau merapat ke garis diagonal maka data dalam penelitian ini normal atau berdistribusi normal. Selanjutnya berdasarkan Uji Kolmogorov-Smirnov berdistribusi normal dilihat dari nilai Sig. $>\alpha$ atau $0,200>0,05$.

\section{2) Uji Multikolinieritas}

Uji multikolinieritas dilakukan untuk mengetahui ada tidaknya hubungan (korelasi) yang signifikan di antara dua atau lebih variabel independen dalam model regresi. Yaitu munculnya peluang diantara beberapa variabel bebas untuk saling 
Jurnal Ekonomi dan Perbankan Syariah

Vol. 3. No.1, April 2015: 55-60, ISSN (cet): 2355-1755

berkorelasi, pada praktiknya multikolinearitas tidak dapat dihindari. Mengukur multikolinearitas dapat dilihat dari nilai Tolerance dan Variance Inflation Factor (VIF). Tolerance mengukur variabilitas variabel independen lainnya. Jadi nilai tolerance yang rendah sama dengan nilai VIF tinggi karena VIF $=1 /$ tolerance. Nilai cut off yang umum dipakai untuk menunjukkan adanya multikolinearitas adalah nilai tolerance $<0.10$ atau sama dengan VIF > 10. Deteksi adanya multikolinieritas dilakukan dengan menggunakan uji korelasi parsial antar variabel independen, kemudian dapat diputuskan apakah data terkena multikolinieritas atau tidak, yaitu dengan menguji koefisien korelasi antar variabel independen. Suatu model regresi yang baik adalah tidak terjadi multikolinieritas antar variabel independen dengan variabel dependen (Gujarati, 2007:67). Setelah diolah menggunakan aplikasi SPSS 22.0 maka terlihat hasil sebagai berikut.

Tabel 4.3 Hasil Uji Multikolinieritas

Coefficients"

\begin{tabular}{|c|c|c|c|c|c|c|c|}
\hline \multirow[b]{2}{*}{ Model } & \multicolumn{2}{|c|}{ Unstandardized Coeffic ients } & \multirow{2}{*}{$\begin{array}{c}\begin{array}{c}\text { Standardized } \\
\text { Coeffir ients }\end{array} \\
\text { Beta }\end{array}$} & \multirow[b]{2}{*}{$t$} & \multirow[b]{2}{*}{ Sig. } & \multicolumn{2}{|c|}{$\begin{array}{l}\text { Collinearity } \\
\text { Statistics }\end{array}$} \\
\hline & $\mathrm{B}$ & Std. Error & & & & Tolerance & VIF \\
\hline 1 (Constant) & -693100869.118 & 101482678.288 & & -6.830 & .000 & & \\
\hline $\mathrm{X} 1$ & 109143.417 & 6987.212 & .905 & 15.620 & .000 & .692 & 1.445 \\
\hline $\mathrm{X}_{2}$ & -15441015.823 & 13831192.988 & -.065 & -1.116 & .270 & 692 & 1.445 \\
\hline
\end{tabular}

a. De pendent Variable: $Y$

Sumber: Data diolah

Berdasarkan tabel 4.3 diatas, nilai tolerance variabel bebas volume bagi hasil deposito mudharabah $=0,692$, dan Kurs Valuta Asing USD =0,692 sedangkan nilai VIF variabel bebas volume bagi hasil deposito mudharabah $=1,445$, dan Kurs Valuta Asing USD $=1,445$. Dapat disimpulkan bahwa model regresi dinyatakan bebas dari multikolinearitas karena nilai tolerance $>0,10$ dan nilai $\mathrm{VIF}<10$.

3) Uji Heteroskedastisitas.

Heteroskedastisitas yaitu kondisi dimana semua residual atau error mempunyai varian yang tidak konstan atau berubah-ubah. Untuk mengetahui apakah suatu data bersifat heteroskedastisitas atau tidak, maka perlu pengujian. Pengujian heteroskedastisitas pada penelitian ini menggunakan metode analisis grafik Scatterplot. Berikut adalah hasil dari metode yang dilakukan Metode Analisis Grafik Scatterplot.:

\section{Gambar 4.2 Scatterplot}

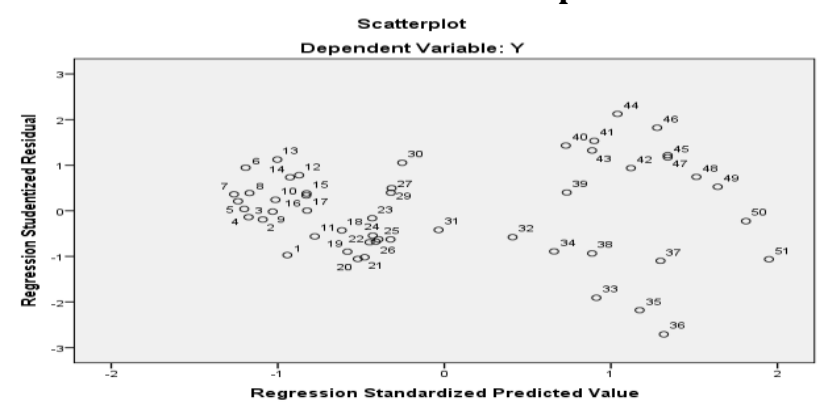

Sumber: Data diolah 
64 | Pratiwi \& Lukmana: Pengaruh Kurs Valuta Asing dan Tingkat Bagi Hasil Terhadap Volume Deposito Mudharabah...

Berdasarkan tampilan Scatterplot pada gambar 4.3 di atas maka dapat disimpulkan bahwa plot menyebar secara acak diatas maupun dibawah angka nol pada sumbu Regression Studentized Residual. Oleh karena itu pada model regresi yang dibentuk dinyatakan tidak terjadi gejala heteroskedastisitas.

\section{4) Uji Autokorelasi}

Uji Autokorelasi bertujuan untuk mengetahui apakah ada korelasi antara anggota serangkaian data observasi yang diuraikan menurut waktu (time-series) atau ruang (cross section). Salah satu ukuran dalam menentukan ada tidaknya masalah Autokorelasi adalah dengan uji Durbin-Watson (DW). Berikut adalah hasil uji Autokorelasi dengan metode Durbin Watson (DW) pada tabel 4.4 di bawah ini:

Tabel 4.4 Hasil Uji Durbin Waston

Model Summary

\begin{tabular}{|l|c|r|r|r|c|}
\hline Mbdel & R & R Square & $\begin{array}{c}\text { Adjusted R } \\
\text { Square }\end{array}$ & $\begin{array}{c}\text { Std. Emor of the } \\
\text { Estimate }\end{array}$ & $\begin{array}{c}\text { Durbin- } \\
\text { Watson }\end{array}$ \\
\hline 1 & $.943^{2}$ & .888 & .884 & 58468392.792 & .603 \\
\hline
\end{tabular}

a. Predictors: (Constant), X2, X1

b. Dependent Variable: $Y$

Sumber: Data diolah

Berdasarkan pada tabel 4.4 diatas nilai Durbin-Watson (DW) sebesar 0,603. Maka dapat disimpulkan pada model regresi ini tidak terdapat gejala Autokorelasi karena nilai DW diantara -2 dan +2 .

\section{Koefisien Determinasi (R Square)}

Koefisien determinasi atau $R$ square merupakan besarnya kontribusi variabel bebas terhadap variabel terikatnya. Semakin tinggi koefisien determinasi, semakin tinggi kemampuan variabel bebas dalam menjelaskan variasi perubahan pada variabel terikatnya. Koefisien determinasi memiliki kelemahan, yaitu bias terhadap volume variabel bebas yang dimasukkan dalam model regresi di mana setiap penambahan satu variabel bebas dan volume pengamatan dalam model akan meningkatkan nilai R Square meskipun variabel yang dimasukkan tersebut tidak memiliki pengaruh yang signifikan terhadap variabel terikatnya. Untuk mengurangi kelemahan tersebut maka digunakan koefisien determinasi yang telah disesuaikan, Adjusted $R$ Square $\left(\mathrm{R}^{2}{ }_{\text {adj }}\right)$. Koefisien determinasi yang telah disesuaikan berarti bahwa koefisien tersebut telah dikoreksi dengan memasukkan volume variabel dan ukuran sampel yang digunakan. Dengan menggunakan koefisien determinasi yang disesuaikan maka nilai koefisien determinasi yang disesuaikan itu dapat naik atau turun oleh adanya penambahan variabel baru dalam model.

Tabel 4.5 Adjusted R Square $\left(R^{2} a d j\right)$ Model Summary

\begin{tabular}{|l|r|r|r|r|}
\hline Model & R & R Square & $\begin{array}{l}\text { Adjusted R } \\
\text { Square }\end{array}$ & $\begin{array}{l}\text { Std Error of } \\
\text { the Estimate }\end{array}$ \\
\hline 1 & $.943^{\star}$ & .888 & .884 & $\begin{array}{r}58468392.79 \\
2\end{array}$ \\
\hline
\end{tabular}

a. Predictors: (Constant), X2, X1

Sumber : Data diolah 
Jurnal Ekonomi dan Perbankan Syariah

Vol. 3. No.1, April 2015: 55-60, ISSN (cet): 2355-1755

Besarnya angka Adjusted $R$ Square adalah 0,884 atau sebesar 88,4\%. Dapat disimpulkan bahwa pengaruh tingkat bagi hasil deposito Mudharabah USD dan Kurs USD terhadap volume deposito Mudharabah USD pada perbankan syariah adalah 88,4\%, sedangkan sisanya sebesar 11,6\% (100\% - 88,4\%) dipengaruhi oleh variabel-variabel lain yang tidak dimasukkan ke dalam penelitian ini seperti Capital Adequacy Ratio, Financing to Deposit Ratio, Return On Asset, PDB, tingkat pengangguran, BI rate, Inflasi dan lainnya. Adapun angka koefisien korelasi (R) menunjukkan nilai sebesar 0,9643 yang menandakan bahwa hubungan antara variabel bebas dan variabel terikat adalah kuat karena memiliki nilai lebih dari 0,5 $(\mathrm{R}>0,5)$ atau $0,943>0,5$.

\section{Pengujian Hipotesis}

\section{A. Uji F}

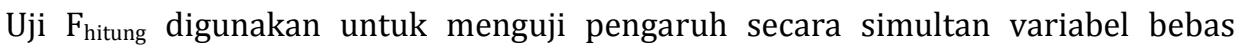
terhadap variabel terikatnya atau untuk menguji ketepatan model (goodness of fit). Jika variabel bebas memiliki pengaruh secara simultan (bersama-sama) terhadap variabel terikat maka model persamaan regresi masuk dalam kriteria cocok atau fit. Sebaliknya, jika tidak terdapat pengaruh secara simultan maka masuk dalam kategori tidak cocok atau not fit.

Adapun cara pengujian dalam uji $\mathrm{F}$ ini, yaitu dengan menggunakan suatu tabel yang disebut dengan Tabel ANOVA (Analysis of Variance) dengan melihat nilai signifikasi (Sig $<0,05$ atau $5 \%$ ). Jika nilai signifikasi $>0,05$ maka $\mathrm{H}_{1}$ ditolak, sebaliknya jika nilai signifikasi $<0,05$ maka $\mathrm{H}_{1}$ diterima.

Tabel 4.6 Hasil Uji F

ANOVA ${ }^{\circ}$

\begin{tabular}{|l|c|r|r|r|r|}
\hline Model & Sum of Squares & Df & Mean Square & F & Sig. \\
\hline Regressi & 1307492017948037 & 2 & 653746008974 & 191.235 & $.000^{\mathrm{b}}$ \\
on & 120.000 & 2 & 018560.000 & 191.25 & \\
Residual & 1640905418732872 & & 341855295569 & & \\
& 00.000 & 48 & 3483.000 & & \\
Total & 1471582559821324 & 50 & & & \\
& 290.000 & & & & \\
\hline
\end{tabular}

a. Dependent Variable: $Y$

b. Predictors: (Constant), $\mathrm{X} 2, \mathrm{X} 1$

Sumber: Data diolah

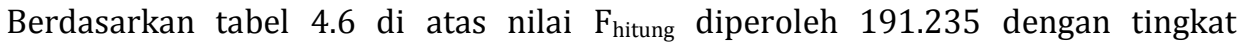
signifikansi 0,000, karena tingkat signifikasi lebih kecil dari 0,05 maka $\mathrm{H}_{0}$ ditolak atau $\mathrm{H}_{1}$ diterima dan nilai $F_{\text {hitung }}>F_{\text {tabel }}(191.235>2$,958) dengan nilai $F$ tabel df: $\alpha$, $(\mathrm{k}-1),(n-k)$ atau 0,05, (4-1), (51-2) = 2,958. Dapat disimpulkan bahwa kurs USD dan tingkat bagi hasil deposito mudharabah berpengaruh signifikan terhadap volume deposito mudharabah USD.

\section{B.Uji T}

Setelah melakukan uji koefisien regresi secara keseluruhan, maka langkah selanjutnya adalah menghitung koefisien regresi secara individu atau uji t. Uji $t$ digunakan untuk mengetahui ada tidaknya pengaruh masing-masing variabel 
66 | Pratiwi \& Lukmana: Pengaruh Kurs Valuta Asing dan Tingkat Bagi Hasil Terhadap Volume Deposito Mudharabah...

independen secara individual (parsial) terhadap variabel dependen yang diuji pada tingkat signifikasi (Sig. 0,05 atau 5\%) maka variabel independen berpengaruh terhadap variabel dependen.

Tabel 4.7 Hasil Uji T

Coefficients ${ }^{\circ}$

\begin{tabular}{|c|c|c|c|c|c|c|}
\hline \multirow{2}{*}{\multicolumn{2}{|c|}{ Model }} & \multicolumn{2}{|c|}{ Unstandardized Coefficients } & \multirow{2}{*}{$\begin{array}{c}\begin{array}{c}\text { Standardized } \\
\text { Coefficie nts }\end{array} \\
\text { Beta } \\
\end{array}$} & \multirow[b]{2}{*}{$t$} & \multirow[b]{2}{*}{ Sig. } \\
\hline & & $\mathrm{B}$ & Std. Error & & & \\
\hline \multirow[t]{3}{*}{1} & (Constant) & -693100869.118 & 101482678.288 & & -6.830 & .000 \\
\hline & $\mathrm{X} 1$ & 109143.417 & 6987.212 & .905 & 15.620 & .000 \\
\hline & $x 2$ & -15441015.823 & 13831192.988 & -.065 & -1.116 & .270 \\
\hline
\end{tabular}

\section{Uji-t terhadap Kurs USD}

Hasil perhitungan yang didapat pada tabel 4.7 variabel kurs USD secara statistik menunjukkan hasil yang signifikan pada nilai lebih kecil dari $\alpha(0,000<0,05)$. Sedangkan nilai t hitung X1 = 15.620 dan $\mathrm{t}$ tabel sebesar 2.958 ( $\mathrm{df}(\mathrm{n}-\mathrm{k}) 51-2=49, \alpha=0,05)$, sehingga $t$ hitung $>\mathrm{t}$ tabel $(15.620>2.958)$. Maka Ho ditolak atau menerima $\mathrm{H}_{1}$ sehingga dapat disimpulkan bahwa variable kurs USD berpengaruh positif signifikan terhadap volume deposito mudharabah USD.

Begitu pula dengan hasil penelitian Panjiwijaya (2013), penelitian yang dilakukannya yakni untuk mengetahui apakah nilai tukar rupiah, tingkat bunga SBI deposito valas, risiko premium, dan inflasi berpengaruh secara signifikan terhadap volume deposito valas di Indonesia. Juga untuk mengetahui variabel eksplanatori manakah yang paling dominan pengaruhnya terhadap volume deposito valas di Indonesia, dengan menggunakan metode analisis ekonometrik, statistik, dan koreksi kesalahan yang terjadi dalam model regresi OLS deposito valas di Indonesia.

Hasil pengujian dan pembahasan dengan menggunakan berbagai metode pengujian terhadap data yang terkumpul dalam penelitian ini, ternyata dapat disimpulkan bahwa besarnya pengaruh keempat variabel independen hampir memiliki pengaruh yang sama, namun untuk jangka pendek variabel risiko premium yang paling dominan $0,861 \%$ terhadap penurunan volume nominal deposito valas. Sedangkan untuk jangka panjang, variabel nilai tukar rupiah terhadap US dollar yang paling dominan sebesar 1,829\% terhadap kenaikan volume nominal deposito valas. Dapat pula dikatakan, melemahnya nilai tukar rupiah terhadap dollar AS, mencerminkan kondisi perekonomian yang tidak menentu sehingga meningkatkan risiko berusaha yang akan direspon oleh dunia usaha dengan menitipkan uangnya pada bank, termasuk pada bank syariah.

\section{Uji-t terhadap bagi hasil deposito mudharabah USD}

Hasil perhitungan yang didapat pada tabel 4.7 variabel bagi hasil deposito mudharabah USD secara statistik menunjukkan hasil yang tidak signifikan pada nilai lebih besar dari $\alpha(0,270>0,05)$. Sedangkan nilai t hitung $\mathrm{X}_{2}=-1.116$ dan $\mathrm{t}$ tabel sebesar 2.958 (df (n - k) $51-2=49, \alpha=0,05)$, sehingga t hitung < t tabel $(-1.116<2.958$ ). Maka Ho diterima atau menolak $\mathrm{H}_{1}$ sehingga dapat disimpulkan bahwa variable bagi hasil 
Jurnal Ekonomi dan Perbankan Syariah

Vol. 3. No.1, April 2015: 55-60, ISSN (cet): 2355-1755

deposito mudharabah USD berpengaruh negatif tidak signifikan terhadap volume deposito mudharabah USD.

Berbeda dengan pengaruh bagi hasil terhadap volume deposito mudharabah IDR yang diteliti oleh Ani dan Wasilah (2010) yang menyimpulkan bagi hasil deposito berpengaruh signifikan terhadap deposito mudharabah dikarenakan para nasabah dalam menempatkan dananya di bank syariah masih dipengaruhi oleh motif untuk mencari profit sehingga jika tingkat bagi hasil bank semakin besar maka akan semakin besar pula dana pihak ketiga khususnya deposito yang disimpan bank. Hasil yang didapat dari penelitian ini juga berbeda dengan pendapat pandangan kaum monetaris klasik melalui pendekatan Fisher yang menjelaskan bahwa meningkatnya suku bunga akan menaikkan volume uang beredar (M2), berarti simpanan valas yang termasuk bagian dari M2 akan naik pula. Namun demikian hasil penelitian ini, menguatkan pendapat Keynes, yang menganggap bahwa permintaan uang untuk tujuan transaksi dan berjaga-jaga tidak peka terhadap tingkat bunga. Dengan demikian dapat dikatakan masyarakat yang menempatkan dananya pada deposito mudharabah USD perbankan syariah benar-benar memanfaatkan dananya untu tujuan transaksi dan berjaga-jaga, bukan dalam fungsi mencari profit maupun spekulasi.

\section{SIMPULAN}

Variabel kurs USD secara statistik menunjukkan hasil yang signifikan pada nilai lebih kecil dari $\alpha(0,000<0,05)$. Maka Ho ditolak atau menerima $\mathrm{H}_{1}$ sehingga dapat disimpulkan bahwa variable kurs USD berpengaruh positif signifikan terhadap volume deposito mudharabah USD. Hal ini sejalan dengan penelitian Panjiwijaya (2013) yang membuktikan bahwa variabel kurs USD mempengaruhi positif signifikan terhadap deposito valas dalam jangka panjang.

Variabel bagi hasil deposito mudharabah USD secara statistik menunjukkan hasil yang signifikan pada nilai lebih besar dari $\alpha(0,270>0,05)$. Maka Ho diterima atau menolak $\mathrm{H}_{1}$ sehingga dapat disimpulkan bahwa variable bagi hasil deposito mudharabah USD berpengaruh negatif tidak signifikan terhadap volume deposito mudharabah USD. Hal ini menguatkan pendapat Keynes, yang menganggap bahwa permintaan uang untuk tujuan transaksi dan berjaga-jaga tidak peka terhadap tingkat bunga. Dengan demikian dapat dikatakan masyarakat yang menempatkan dananya pada deposito mudharabah USD perbankan syariah benar-benar memanfaatkan dananya untu tujuan transaksi dan berjaga-jaga, bukan dalam fungsi mencari profit maupun spekulasi.

Secara simultan, bagi hasil deposito mudharabah USD dan Kurs USD berpengaruh signifikan terhadap volume deposito mudharabah USD. Besarnya angka Adjusted $R$ Square adalah 0,884 atau sebesar 88,4\%. Dapat disimpulkan bahwa besarnya pengaruh bagi hasil deposito Mudharabah USD, dan Kurs USD terhadap Volume Deposito Mudharabah USD pada perbankan syariah adalah 88,4\%, sedangkan sisanya sebesar 11,6\% dipengaruhi oleh variabel-variabel lain yang tidak dimasukkan ke dalam penelitian ini seperti Capital Adequacy Ratio, Financing to Deposit Ratio, Return On Asset, PDB, tingkat pengangguran, BI rate, Inflasi dan lainnya. 
68 | Pratiwi \& Lukmana: Pengaruh Kurs Valuta Asing dan Tingkat Bagi Hasil Terhadap Volume Deposito Mudharabah...

\section{DAFTAR PUSTAKA}

Arifin, Zainul. 2009. Dasar-Dasar Manajemen Bank Syariah. Azkia Publisher. Jakarta.

Andriyanti, Ani, S.E. dan Wasillah, S.E., Ak., M.E. 2010. "Faktor-Faktor yang Mempengaruhi Volume Penghimpunan Dana Pihak Ketiga (Deposito Mudharabah 1 Bulan) Bank Muamalat Indonesia (BMI)."

Eastspring investments. 2015. "Market Outlook 2015".

Husni, Azhary. 2009. "Faktor-Faktor yang Mempengaruhi Penghimpunan Dana Pihak Ketiga pada Perbankan Syariah di Indonesia Periode: Januari 2006-Desemberb 2007". Jurnal Ekonomi dan Bisnis.

Karim, Adiwarman. 2004. "Bank Islam Analisis Fiqih dan Keuangan”. PT. Raja Grafindo Persada. Jakarta.

Kurniawan, Henricus Nomi. 2003. "Analisis Faktor-faktor Yang Mempengaruhi Volume Simpanan Valuta Asing Bank Umum Di Indonesia 1997-2001".

Muttaqiena, Abida. 2013. "Analisis Pengaruh PDB, Inflasi, Tingkat Bunga, dan Nilai Tukar Terhadap Dana Pihak Ketiga Perbankan Syariah di Indonesia 2008-2012".

Panjiwijaya, Gilang. 2013. "Analisis Faktor-faktor Yang Mempengaruhi Deposito USD di Indonesia".

Sudarsono, Heri. 2003. "Bank dan Lembaga Keuangan Syariah (deskripsi dan ilustrasi)". Ekonisia, Yogyakarta.

Undang-Undang Nomor 21 Tahun 2008 tentang Perbankan Syariah.

Wiroso, S.E., M.B.A. 2005. Penghimpun Dana dan Distribusi Hasil Usaha Bank Syariah, PT. Grasindo, Jakarta.

Yuliati, Sri Handaru dan Prasetyo, Handoyo. 1998. Dasar-dasar Manajemen Keuangan Internasional. Edisi Pertama. Cetakan Pertama. Yogyakarta.

http://www.bi.go.id/statistikkeuangan 